Vol. 13, n² | 2009

Varia

\title{
Men Committing Female Crime: Infanticide, family and honor in Italy, 1890-1981
}

Patrizia Guarnieri

\section{(2) OpenEdition}

Electronic version

URL: https://journals.openedition.org/chs/1108

DOI: $10.4000 /$ chs. 1108

ISSN: 1663-4837

Publisher

Librairie Droz

\section{Printed version}

Date of publication: 1 October 2009

Number of pages: 41-54

ISBN: 978-2-600-01387-1

ISSN: $1422-0857$

\section{Electronic reference}

Patrizia Guarnieri, "Men Committing Female Crime: Infanticide, family and honor in Italy, 1890-1981", Crime, Histoire \& Sociétés / Crime, History \& Societies [Online], Vol. 13, n² | 2009, Online since 01

October 2012, connection on 23 March 2022. URL: http://journals.openedition.org/chs/1108; DOl: https://doi.org/10.4000/chs.1108 


\title{
Men Committing Female Crime: Infanticide, family and honor in Italy, 1890-1981
}

\author{
Patrizia Guarnieri ${ }^{1}$
}

L'infanticide est généralement considéré comme une infraction typiquement féminine. Cette caractérisation sexuée sert fréquemment d'explication au fait que, dans la deuxième moitié du XIX $X^{e}$ siècle, ce crime passa du statut de crime capital à un statut de moindre gravité. On a affirmé que cette atténuation était due à la condition malheureuse de la meurtrière et les travaux historiques l'ont généralement dépeinte comme une femme séduite et abandonnée. Le présent article entend au contraire démontrer que la législation italienne, à partir du premier Code pénal de 1890 prévoyait une punition légère principalement au bénéfice des hommes qui tuaient un enfant pour défendre leur honneur masculin. Ce fut encore plus visible sous la législation fasciste de 1930, et jusqu'en 1981, lorsque la circonstance atténuante de l'honneur fut abolie. Ce n'est qu'alors que l'infanticide devint une infraction féminine et maternelle. La loi nouvelle conserve cependant de nombreux défauts.

Infanticide is usually considered as a typically female offence. This gendered characterization is often used to explain why, in the second half of the nineteenth century, this crime was transformed from a serious one, punished with death penalty, to a lesser offence. It has been argued that punishment was reduced because of the unfortunate conditions of the murderess. And historical studies have usually portrayed the offender as a woman who was seduced and abandoned. This article will demonstrate instead that Italian legislation, beginning with the first Penal Code in 1890, mandated light punishment above all for the benefit of the men who killed an infant to defend their male honor. This was even more apparent under the Fascist law of 1930 until 1981 when honor was dropped as an extenuating circumstance. Only then infanticide became a female, maternal crime. Yet, the new Italian law has many flaws.

$\mathrm{I}$ would like to begin with a fiction in the archive of the Criminal Court of Florence $^{2}$. On June 16, 1889, a 14-year-old boy happened upon the deteriorated corpse of a baby in a ditch in Sesto Fiorentino, a town near Florence. The local

\footnotetext{
1 Patrizia Guarnieri is associate professor of contemporary history at the University of Florence and in the International Doctorate on «Citizenship, rights and gender equality in modern and contemporary history », at the University of Naples L'Orientale.

2 For the quoted expression I obviously refer to Zemon Davis (1987, especially pp. 3-4). My archival sources are in Archivio di Stato di Firenze, Tribunale di Firenze. Atti Penali, s. Processi risolti con sentenza, 1889,899 , b. 1323.
} 
police arrived upon the scene and a few days later discovered that a woman in the town named Ottavia had been pregnant. But she no longer was so, nor was there any baby to be seen. Ottavia was 29 years old and had two small children. She was a straw weaver and a widow. The town midwife was interrogated, and confirmed that she had examined the woman at the $8^{\text {th }}$ month of pregnancy and had since heard that the baby had been delivered. At that point the carabinieri (a sort of national police corps) went to visit Ottavia, carried out a rather "astute interrogation" and arrested her. She admitted to having given birth to a live son, but claimed she had not caused his death. After lengthy investigation, the doctors established that the baby had been born more than six weeks before being found, and that his cranium had been crushed. Following her arrest, the woman went before the judge to accuse her lover of the past year, but this man was nowhere to be found. Strangely enough, the judge sent out forces to search for this man, a certain Raffaello, who was 48 years of age, a stagecoach driver, married with three children and apparently in hiding. He was then apprehended, arrested, and both were accused, she for infanticide and he for homicide.

From the papers of the trial, we can see that in this kind of crime narrative, in which the woman usually appears to be alone, there are in fact many different voices present: the official midwife, a medium contacted by the man to discover if his lover was really pregnant, another woman to procure an abortion, and a few men cited by Raffaello as her lovers; other actors included a hotelkeeper, the carabinieri, neighbors, and others from the town as well as from Florence. But most importantly, we are presented with a man and a woman who, accusing each other of the death of the baby, reveal a remarkably different emotional perception and experience of their relationship as a couple.

I must, however, interrupt the narrative at this point, resisting the temptation to continue in my vein as micro-historian, but I will return to it later. This brief story raises several questions, more than we are able to answer with what is generally known about the history of infanticide. That is why I chose this specific case study among various others, as it presents rather unusual features, beginning with two factors. First, the judicial inquiry looks not only at the mother's responsibility, but takes into account that of the father too; his intention was not to appear at all. Instead the authorities searched for him. Second, the two are charged with different offenses-infanticide and homicide respectively - for the same criminal deed: the killing of their newborn son. The trial took place in 1889 in Florence, just before the first unitary penal code came into force in all of Italy, almost thirty years after the country's unification ${ }^{3}$. The judicial context in which infanticide was defined in this new Italian criminal code of 1890 - and then through the fascist one and then that of the republic up to the present law, established in 1981 - appears to be very different from the legal and cultural framework which preceded 1890. Suddenly, this new legal context put aside very complex questions that had been taken into consideration before, especially in Tuscan law, and left them completely unanswered. With

Until 1890 Tuscany had been the only region which had maintained its own penal code, under many respects the most advanced, while in all the other provinces of the Kingdom the hegemony of the House of Savoy over the process of national unification had meant an extension of its penal code (Sardinia-Piedmont) over the national territory after unification in 1860-1861. 
the disorientation that my brief opening narrative of Ottavia and Raffaello might provoke, at the beginning of an analysis of infanticide in modern Italian legal history, I would like to stress that removal and ignorance have weighed terribly up to the present time and that a re-examination of the past is needed. In order to do it effectively, I believe that we need a methodological proposal for a new approach. I would like to underline that, if we intend to rethink infanticide by cases -that is, to reason from the singularity - then it is necessary to rid the field of a few misconceptions and to discuss some commonplace issues ${ }^{4}$. To do this, we need to analyse laws and the corpus of jurisprudence, apparently not so fascinating, but that, in our case, are full of surprises.

I came to this also by looking at our present situation. In today's crime news, at least in the Italian media, there are an amazing number of cases of very young children being killed ${ }^{5}$. In Italy public opinion is convinced that infanticide is on the increase, while criminologists consider it a crime which is almost extinct all over Europe and especially in Italy ${ }^{6}$. How do we explain the gap between what the general public perceives and what the statistics of the experts affirm? Certainly, we are talking about two different things, meaning that the public considers any killing of small children as infanticide, without taking into account the selective criteria contained in law. On the other hand, it is precisely these criteria that make the law appear anachronistic, say the jurists. For a variety of reasons, we are not able to fit what happens in reality to one model.

What the law says and what people see is that the person who commits infanticide is given a light sentence, so she is in some way excused. What could be the reason behind this? The most common perception is the persistent idea that the mother who kills her own child is alone, single, abandoned, and with financial problems that prevent her from supporting her child. This is a reassuring stereotype of the past compared to the reality that mothers who kill are usually married, in the upper-middle class income bracket, and are not suffering from evident psychiatric pathologies. The stereotype, instead, strongly echoes (almost as if it were influenced by it) the historiographic thesis that holds the child killer of yesteryear to have been usually seduced and abandoned.

Perhaps we need to take into consideration the idea that is finally gaining ground among social scientists that "current trends need to be understood in their historical context", because a number of policies and legislative actions - which are not usually receptive to the contribution of historians - seem to base themselves on historical beliefs and axioms without being aware of doing so, and without adequate awareness of the changes that have occurred in the meantime ${ }^{7}$. Here we refer to our idea of family, of assistance, including support figures for the most vulnerable mem-

See Passeron, Revel (2005).

5 Recent cases outside Italy might include the little English girl, Madeleine McCann, who disappeared in Portugal on May 2007 and whose mother has been suspected by the police (until July 08).

6 Some experts stress that, on the other hand, there is an increasing number of mothers who kill their children and are considered not criminal but insane; see Ponti, Fiorentini (1887-1891, p. 158), with data of infanticide in Italy from 1950 to 1981 and more recent data in Merzagora (1992) and Ciappi (2002, pp. 84-89).

7 This is a central point, for ex., in the interdisciplinary project with an anthropological agenda funded by the European Union's Sixth Framework Programme, Kinship and Social Security regarding 8 European countries, Italy included, and coordinated by Patrick Heady; see http://www.eth.mpg.de/kass/. 
bers of the family, and especially of those who run the risk of becoming either victims or perpetrators of family crimes in those infanticides committed nowadays by women with families.

Let us focus more closely on the typical profile of the perpetrator of infanticide as she emerges from the history of such cases. We already know many of them - in Italy I find in Prosperi's recent book, Dare l'anima (Giving the soul), a classic case. Lucia is a servant who lives alone with her widowed mother, and who is seduced by no other than a priest encountered on the eve of Carnival in 1709, during the celebrations in the streets of Bologna. The court, which at that time and place depended on the law of the Papal States to which Bologna belonged, condemned her to a painful death by guillotine without burial, unless she repented publicly in order to save her soul. The story itself fires the imagination and is rendered powerfully by Prosperi: it has all the right ingredients. Even later, for at least two centuries, women who killed their children would continue to correspond to Lucia's profile: a lonely servant-girl with no family protection, whether raped or not by a man who moves in and out of her life without leaving a trace ${ }^{8}$.

What changes after the Napoleonic Code during the second half of the $19^{\text {th }} \mathrm{C}$. is the length of the penalty for the infanticide which is reduced considerably to a maximum of around 10 years. How are we to explain this? I would suggest that the focus had shifted radically, and that the sentence was not determined on the basis of the identity of the most defenceless victim in the world, the newborn baby, but of the author of the crime and the motivation for it. That is why infanticide is so fascinating in the history of law : from a 'botanical' correspondence between crime and punishment to a vision which admits a variety of subjective motivations; from "who did it?" to "who exactly this person is and why he/she did it"9.

Because we are looking at the female author of infanticide instead of the infant, we might say that the crime came to be punished less because women were punished less. In general, crimes carried out by females are considered less serious than those committed by males, as has also been suggested by the authors and editors, Margaret L. Arnot and Cornelie Usborne, of Gender and crime in modern Europe ${ }^{10}$. However, this response, which is based on the female gender of the perpetrators of infanticide, does not leave us completely satisfied.

There are two main aspects that this hypothesis cannot explain. 1) The punishment for this extreme offence against an infant loses ground exactly when the child finally acquires importance: in the second half of the $19^{\text {th }} \mathrm{C}$. children become the autonomous objects of scientific investigation and are no longer studied as miniature adults. Most importantly, their existence and growth is no longer seen as the private affair of the family, but as a resource for the nation and society in its entirety. 2) A reduced penalty, apparently conceded to the gender considered less criminal,

8 See, for ex., Pelaja (1981), Casarini, and, of course Prosperi (2006). Outside Italy, Ruggiero (1992) and see the collected essays in Jackson, M., (ed.), Infanticide. Historical perspectives on child murder and concealment 1550-2000, Aldershot- Burlington, Ashgate Pub., 2002; Schulte, R., The village in court. Arson, infanticide and poaching in the court records of Upper Bavaria 1848-1910, Cambridge, Cambridge University Press, 1994 (or. ed. 1989).

9 This passage from one question to the other one was pointed by Foucault (1978) who in fact chose to talk about some supposed infanticides as the most significant cases in his course on Les anormaux 1974-1975 (1999).

10 See Arnot and Usborne (eds.) (1999). 
refers in reality also to men - indeed, it is intended in particular for them, in my estimation. Men are often present in cases of infanticide, even if historians do not seem to have dedicated much attention to them.

The historiographic proposal which emerges from the book previously cited, as regards gender and crime, was correctly the following: let's look for more women in the history of crime which seems to be a sphere acted out and judged exclusively be men, and where women only appear as victims, or secondary figures (accomplices) or where they are guilty of minor offences (even when they are the authors of lifethreatening crimes such as infanticide $)^{11}$. I share the views expressed by Arnot and Usborne but my proposal here is that we start looking for the men involved in socalled female crimes such as infanticide, or prostitution etc.

Why should we women historians also let men get away and disappear from the scene of the crime? They have often left behind important clues and traces of evidence, and finding them would allow us to understand a great deal. Certainly, they have left many fingerprints in the legislation, and that is why I propose a new focus on the laws, before we continue examining the cases. From this new angle, Italian legislation is extremely interesting. The first Italian Penal Code, effective from thirty years after the unification of Italy, is the Zanardelli Code of 1889-90. The second Penal Code, entitled Rocco P.C., dates back to 1930, but in 1981 the law on infanticide changes, and therefore we have had three different laws on that crime from 1890 to the present. That is not all: before 1890 there were both the Sardinian Penal Code which was extended to the rest of Italy after 1861, and the Tuscan PC: Tuscany refused to give up its much-admired legislation by which the death penalty had been abolished as early as 1786 . And, of course, before 1861 there were the various pre-unification states, each with their own codes.

The first surprise when we observe the changes in the Italian legislation is that this crime, which is now considered essentially female and maternal, has only been so in law for the past 26 years. The law of 1981 is the first in Italy to define infanticide as exclusively the crime of a mother who kills her newborn baby under predefined circumstances. We will examine these shortly. While it is true that, according to the Napoleonic Code, it was illegal to search for the fathers of illegitimate children, as explained by Rachel Fuchs ${ }^{12}$ and this ban on paternity searches was imitated by the Italian Civil Code of $1865^{13}$, the laws on infanticide before 1981 made reference to men, and this is an Italian peculiarity ${ }^{14}$. But who exactly were they referring to?

In the Penal Code of 1890 , at art. 369 , there is a sort of indirect list, which refers to the mother of the infant: these men were (her) brothers, father (natural or by adoption) and husband. Consequently, the mother was not always a single woman but

11 Arnot, Usborne, 1999. It is interesting that the same proposal - let's study women as criminals not only as victims - comes from a group of psychologists and social scientist who work with juvenile delinquents nowadays. They argue that specific strategies to prevent and cope with girls who committed crimes, and denounce a lack of analysis by gender: See Ciuffi et alii (Eds.) (2007).

12 See Fuchs' essay in this volume.

13 Cfr. Romanelli (1995).

14 The infanticide has exclusively been referred to the mother of the victim in other countries, unless in Spain where the mother's parents were considered too (P.C. 1826). See also the case of Italian mothers under trial for alleged infanticide in Argentina (P.C., 1887 like the Spanish one) discussed by Kristen Ruggiero (1992). 
sometimes an adulteress. All of the other male authors of infanticide are given the same punishment as the mothers, meaning from 3-10 years in prison.

In 1930, art. 578 PC opens up the list to include even more male figures, and not just the woman's family members but 'anyone'. The law states, in these precise words, "Whoever provokes the death of a newborn immediately after birth or of a foetus during delivery..."15. Actually, there is no distinction in punishment for accomplices to the crime, who receive the same sentence of 3-10 years.

Summing up, the possible authors of infanticide are therefore the mother, close male family members until 1890, and many others after 1930 . Who might these others be? Jurists of the time tell us that Fascist legislators had in mind above all the fathers of the infants who had been murdered - the lovers of those women who had not procured an abortion, having given birth to a child that the man rejected. I have said 'fathers' but, significantly, no one ever uses this word to refer to them as they do not want to acknowledge the child; these men are not attached to their biological paternity. On the contrary, women are always defined as mothers, with no consideration of the fact whether they ever wanted to be pregnant. These men may have murdered the child themselves, but the other novelty of the 1930 law is that they could also, as could the illegitimate mother's relatives, avoid dirtying their hands: anyone who committed this crime would be accused only of minor homicide, if he had acted according to the motivations foreseen in the code or for the "purpose of favoring anyone involved" who had those motivations.

What might these motivations be? This is the fulcrum of our thesis. The light penalty does not depend on the presumed female nature of this crime, but rather on the motivation which defines it as second-class homicide, and that categorizes it therefore as a male as well as female crime. The same formula is used in 1890 and 1930 to define this motive, which is to save one's honor. Whose honor, we may ask? The mention of 'one's own honor' in the first Italian law indicated the honor of the illegitimate mother or adulteress, the loss of which was to be felt not only, nor necessarily, by the woman herself ${ }^{16}$, but also and above all by the men she was related to as wife, sister, descendent or adopted daughter. The legal texts of this period praise the legislators who had seen fit to diminish the punishment of not only the woman but also of male relatives, who also lost honor. A woman and a man's honor were one and the same: her chastity and her faithfulness. Those were not reciprocal, but applied exclusively to the female gender.

In a way, infanticide in 1890 is seen as a family crime, not because it offends the family, but paradoxically because it intends to protect it. Naturally, the family was conceived as one with a male head (the father of the pregnant woman or prospective husband) in which men are considered more important and the only ones designated to make decisions. Do we think that the woman who had just delivered a baby was consulted regarding her original intentions for her baby and herself, when it was clear that it was the father, brother, or husband who took the infant from its mother and killed or abandoned it? The mother's will was not taken into consideration, but instead the will of whoever had killed or abandoned her child. This regarded, in any case, the family of the illegitimate mother or adulteress, and therefore the list of pos-

15 See art 578 Italian P.C. 1930, and Manzini (1964, pp. 56-75).

16 In the late seventies Edith Saurer (1978) already questioned, regarding the British context, that honor was ever the main reason for mothers committing infanticide. 
sible perpetrators of infanticide foreseen in art. 369 did not include non-family members.

In the 1930 law this limitation has disappeared. Anyone was in a position to act to save their own honor, which clearly no longer referred only to women (whose honor was a male gender construction and was defended by male family members), but also to men. Family honor involved the defence of the family as an abstract legal institution - not the flesh and blood family of the single woman, but also the married seducer's family (who remained unaware of the behaviour of their Don Giovanni and the birth of a baby) or even his eventual future family (if he was a bachelor). This abstract but legal institution of the family held that any man could contract a regular marriage that would later produce his own legitimate children, so much the better if they were males.

The law of 1890 had not contemplated the case of "a man with family who must conserve its tranquillity and social position". Incredibly, fascist legislation dealt with that omission: if the man "destroyed the evidence of his past acts that could ruin his future», he had to be favoured with attenuating circumstances for having killed in order to save his reputation ${ }^{17}$. The prominence of male honor is finally clear in law. Therefore, to save his honor, it is the man who refuses to acknowledge fatherhood - a word that is never mentioned - as a natural instinct or a responsibility. We could add that this enormous tolerance during fascism regarded not only the killing, but also the abandonment of a newborn by anyone (art. 578 and art. 592 C.P. 1930). Despite its rhetoric glorifying the mamma italiana, Fascist legislation effectively gave men more power to operate independently with little regard for the woman; she was stripped of any chance of making decisions about herself and her baby.

In 1981 the law no. 492 abolished any and all attenuating factors regarding motives of honor and therefore all the laws that had contemplated it were abrogated or altered. Consequently, the text of art. 578 of the Penal Code had to be radically altered: men disappeared from the scene of the crime and from the definition of infanticide. Today, an accusation of infanticide can be brought only against the mother who acts not to save anyone's honor, but because she has suffered "conditions of abandonment $[\ldots]$ connected to childbirth" (art. 578, from 1981). With this change in motivation, infanticide simply becomes a female and maternal crime. To confirm that earlier light penalties were not intended to favor women, we can observe that sentences have now increased somewhat for the mother (from 4 to 12 years) and instead decreased for accomplices. Accordingly, men risk less than the woman if they act for the "purpose of favouring the mother", as if there weren't other ways of helping her.

At this point we need to take a closer look at the female perpetrator of infanticide, who now appears completely alone, with no one to help her, and indeed in a state of «material and moral abandon», as the law now states. What types of abandonment can diminish her guilt, assuming that she is mentally sane? The only motive for abandonment acknowledged by law as an attenuating factor for killing her own newborn (while the killing of his or her own child is still considered aggravated homicide) is the lack of health assistance at the moment of birth. Moral abandonment may be added to material abandonment, but - here the legislator is very clear - only as a consequence.

17 Carfora (1902-1906, but 1904, p. 714). 
The new jurisdictional definition of infanticide is very restrictive, and also anachronistic. The 1981 law doesn't seem to take into account all the numerous preceding norms that have altered the context in Italy. The main three are the following:

1. since 1974 abortion is legal and medical assistance is provided (this has certainly prevented infanticides);

2. since 1975 the new family law recognizes the equal status of husband and wife and abolishes the legal category of illegitimacy (albeit, ambiguously);

3. since 1978 the National Public Health System guarantees medical assistance to all males and females, with or without Italian citizenship, including female immigrants without any sort of document (the so-called clandestine category) ${ }^{18}$.

Thus medical assistance at delivery is always available, except in the case of women living on the very margins of society. In fact, whenever a mother prefers not to go to the hospital she cannot legally be considered abandoned and therefore justified if she kills her baby, as sentenced by the Italian Supreme Court in $1985^{19}$.

It is evident that most cases of murdered children - that media portray incorrectly as infanticides and turn into a spectacle - do not at all fall into the current judicial definition of this crime. This explains why criminologists call it a crime in extinction, while the public perceives it to be on the increase. Surely, the attention of psychologists and psychiatrists towards (technically non-infanticidal) parents who kill their sons/daughters has grown: mothers who do not fit in the typical profile of the materially abandoned woman (almost all of them have a house, a family and a husband who never detected anything before the impending tragedy), or fathers who often declare or pre-.announce their motivations. Even during judicial enquiries, the use of psychiatric examination - an increasingly frequent means of appraisal in general - has become constant, in the attempt to explain a crime which appears to be socially inconceivable and which is beyond the imagination even of the closest family members of the perpetrator. The systematic resort to psychiatric expertise to establish the mental insanity of the women under investigation is moreover used to avert the most serious charge of child murder otherwise required by the tight requirements of the law on infanticide. But even in the very limited cases which allow the application of the law of 1981, the advisability of keeping it has been questioned. On the one hand, this law refuses preliminarily to take into account any psychological conditions attached to maternity; on the other, it only recognizes serious psychiatric pathology, which, as a result, excludes legal responsibility, as in the case of any crime committed in conditions of mental insanity. However, I'm interested in underlining another aspect of this contradictory and much-discussed law, which is pertinent to our discussion. We all know that juridical definitions are oriented by certain conceptions regarding gender. The female protagonist of infanticide established by the 1981 law is a biological mother, whether married or not, who becomes

18 Since this article was completed, the Italian Senate approved a legislative decree presented by the government of Prime Minister Silvio Berlusconi's that, on grounds of security, contemplates that physicians would denounce to the police illegal migrants when they ask for health care. This decree (d.d.1. 773/ 2009) has aroused a storm of protests, especially from physicians themselves.

19 See Corte di Cassazione (which is the final level of judgment), sez. 1, sent. 16 April 1985, see Ambrosetti's comments on it (1992, p. 50). 
a criminal because she is overwhelmed by that 'natural' event of femininity called childbirth.

It is precisely this concept, I believe, which is the principle anachronism of a law which comes paradoxically after the explosion of the women's movement in Italy which fought for abortion and divorce. The latter measures were approved via referendum by the Italian people, a majority of whom are nominally Catholic, but who do not follow the dictates of the Roman Catholic Church. Instead, the most recent law on infanticide incorporates an almost $19^{\text {th }} \mathrm{C}$. view of women, or rather, a naturalistic one which we normally attribute to the $1800 \mathrm{~s}$. Becoming a mother is limited to giving birth, erasing any other aspect of maternity, including the so called motherhood constellation ${ }^{20}$, and women's experienced relationships, above all, with their child.

Paradoxically, $19^{\text {th }}$ C. codes elaborated a more fully developed cultural concept of the woman who commits infanticide. She committed the act not because she gave birth without any help, but because she was desperate enough to have a child without a father, and thus risked losing not only her highly acclaimed honor but any means of sustenance, male family protection (if she had one), and above all the main possibility for a woman which was a matrimony. She was guilty of only a minor crime because she was entitled to recognition as a victim, not of the natural event of childbirth, but of a cultural mentality which discriminated against her and ruined her life.

Even the formula that establishes the timing of infanticide alluded to cultural and not natural notions in the 1890 PC. When exactly does the act itself take place? The crime has to have taken place "immediately after or during delivery" according to the law of 1930 as well as the present one. In the present version, the timing involved indicates a strict and explicit reference to a traumatic event, female by nature (especially if there is no medical assistance). Interestingly enough, the same timing was applied before 1981 to male perpetrators of infanticide as well, who certainly did not give birth. The reasoning behind this can be understood by examining the previous law of 1890 , which was extremely precise (so much so that it was cut): infanticide was to have been committed "within the first 5 days after birth", because the infant had "still not been written into the birth register". The killing of this child counted less because his/her birth itself (illegitimate) was considered of scarse value and as belonging to the private sphere. Those few who knew of it, beside the mother, could certainly be counted on to keep the double secret: of the lost honor and of the elimination of the 'evidence'.

The nineteenth-century law, in fact, considered the 'illegitimate' child just that, «dishonorable evidence», and that explains why punishments for infanticides due to honor were so reduced, despite the openly acknowledged value of the child in the culture of the late 1800s and 1900s. Finally that question which remains unsolved by the thesis of the female nature of this crime has an answer: the defence both of the most defenceless of all beings and of life as supreme value as declared in juridical texts were sacrificed to protect the legitimacy of the family institution.

Turning our attention to men when we are discussing the most female of crimes restores a real complexity to our picture, and counters the risks of naturalizing and

\footnotetext{
20 I refer to the category of the well-known American psychoanalytical psychotherapist Stern (1995) or to other theories on the internal and relational world of both the mother and the infant.
} 
removing female criminals form their historical context. This is a long-lasting risk, in my opinion, which we usually attribute to the 19th century positivistic idea of woman but is still evident in science, law, and historical research as well. In Italian law, the woman perpetrator of infanticide is, on the one hand, seen sociologically as living on the fringe of society (so much so that she does not even have access to free health care, normally available to everyone), and, on the other hand, as a physical body with neither will nor emotions. Strangely enough, some female members in the Italian Parliament from the Communist and Catholic parties were the ones who requested, in the late Seventies, that the new law ignore psychological and subjective conditions of the mother who committed infanticide, reasoning that these considerations diminished the dignity of a woman and were a by-product of male chauvinism ! $!^{21}$

On the contrary, until 1981 men who killed the dishonoring newborn were seen as being driven by fury and justified for their virile shame, jealousy and rage, and all this in no manner reduced their dignity. Emotions are normally attributed to women, while men are usually recognized as exercising a rational control over their emotions $^{22}$. But here again the tables are turned: emotions are denied to women, and accepted in men and not seen as antithetical to rationality and dominant social values.

Yet, the cases which emerge from our archives spill over with the emotions of those incriminated and of the judges themselves. This is the last aspect to which I would like to draw some attention, aware of having had to neglect many others. When from our sources we are able to uncover not only an isolated woman but a whole network of individuals surrounding her, we are in a better position to understand not only what and how those men and women felt, but how people thought about how to feel and express their feelings ${ }^{23}$. We can perceive shared social values - honor, the legitimacy of birth and maternity, life itself - together with a variety of different individual gender-oriented expectations, emotions and choices. The law of 1981 has finally affirmed that honor, as an excuse for infanticide, no longer represents a value in Italian society; but on the other hand it brought forward a naturalized and a-historical idea of maternity. In this respect too, it seems that a legislation which should have been modernizing was not aware of historical transformation and of the possibilities for the present times that knowledge of the past might have suggested.

Now we are prepared to return to the case we opened this essay with, back to the outskirts of Florence in 1889, so as to better understand some of the questions that we left unanswered (without pretending to exhaust here the analysis of such an intriguing case). Raffaello, the man in our story and Ottavia's lover, told the judge that he had had nothing to do with the dead baby ${ }^{24}$. He had not killed it; it was not his son but someone else's. Ottavia was not his lover - he had gone to her a few

21 See Ravaioli 1979 on the Disegno di legge no. 112 at the Italian Senate. A more detailed reconstruction of these legislative debates is in Guarnieri (2005).

22 For the stereotyped association that gendered honor as male and rational, contrasting with «sentimentality» as female and unreasonable, see Reddy (1997).

23 See Rosenwein's review essay (2002).

24 Trial against Ottavia Cresci and Raffaello Pini, Archivio di Stato di Firenze, Tribunale di Firenze. Atti Penali, s. Processi risolti con sentenza, 1889, 899, b. 1323. 
times, paying her as a prostitute, and other men went too. Who were these other men, the judge asked. Raffaello gave the name of the local carpenter and a few others, but they all denied any involvement when interrogated. She was a good woman, people said; he had been her only lover for a year, and everybody knew it. Ottavia said that Raffaello was with her when the baby was born; as soon as it came out he had let it fall and crushed it in his hands. After this he disappeared for a number of days. When he came back, she wanted to leave him but he convinced her to spend one more night together. When they saw each other again a week later, she was by then even more determined to interrupt the relationship. But when she told him so, he struck her, tried to rape her and threatened to disinter the corpse, and tell everyone that the baby was dead. Ottavia responded that he was the one who had killed it. Raffaello replied that no one would have believed her - it's the woman's fault because she's the one who gives birth. However, this time Ottavia didn't give in.

A few days later Ottavia learned that the body of her little baby had been found and immediately understood that Raffaello intended to ruin her. She hadn't wanted this pregnancy, she cried because she knew that her services as a maid would no longer be requested, and she was ashamed. But she had been concerned about the baby and had even called the midwife to her home more than once, as the midwife herself later confirmed. On the other hand, her lover had reassured her that he would take care of everything, even the midwife, and would have paid her to take the baby to the Spedale degli Innocenti, the well known foundling hospital in Florence ${ }^{25}$. That's why he had taken her bracelet and ring and taken them to the Monte di Pietà (an institution for pawning goods). Didn't he remember, she asked?

The judge before whom they had their confrontation most surely sympathized with the widow. Ottavia is shown as being "moved and energetic" in telling her story in front of her ex-lover, who stood silently after so many lies. Ottavia was certainly not mad -the question of her insanity did not arise ${ }^{26}-$, nor was she foolish - she had already had two children before her husband died. Nor was she the typical seduced and abandoned woman. We are not interested at this point in concluding that she was innocent, that she did not murder her child. The issue is that her story makes us think that the stereotype that infanticide was a typically female and thus minor crime does not hold, because too limiting and often misleading.

We have the obligation to ask ourselves why the female criminal is so reduced to a natural object as to be deprived even of her emotions, while on the contrary men are not, and yet they are judged with equal or more tolerance if they kill a newborn child. This case may suggest that by recognizing Ottavia's emotions, the gap between her ambivalent feelings as a woman and the feelings considered acceptable for a woman in her circumstance was too wide. Perhaps she didn't share the idea that killing her child immediately after birth was a sort of minor offence, as stated in the male-oriented law, which, at any cost, defended the institution of the family headed by men.

25 About the foundling hospital in Florence in those years, and its modernization see Guarnieri 2002 and 2004; also Viazzo, Bortolotto, Zanotto (1994).

26 Very few the infanticide women seemed to go under plea for insanity in the late XIXth C. and early XXth C. Italy, as Selmini (1987) stated and the cases in Florence confirm. The current tendency is the opposite (Friedman, 2005), but it must be noticed that the definition of infanticide as a minor crime has always regarded 'normal' and not pathological mental conditions of the one who committed it. 
As a historian, I should clarify at least one more point about this specific case. I began by saying that Ottavia had been accused of having committed an infanticide, while Raffaello was accused of homicide. This difference can be ascribed to the fact that their trial occurred in Florence, just a few months before the promulgation of the first Penal Code of the unified Kingdom of Italy by Zanardelli. The two lovers were thus not judged according to the Italian laws, whose change I have here analysed; rather, they were judged according to the more advanced Tuscan Penal Code of 1853. Already at that time, this Penal Code considered infanticide as a motherrelated crime (as the Italian laws acknowledged only in 1981), when this was committed against a child born out of wedlock. The Tuscan Law too punished infanticide with "special benevolence"; this crime differed in fact substantially from that of homicide, because the reasons of the mother for committing an infanticide were taken into account. What made the difference between the two were not the physical conditions of the mother, including puerperal fever, but rather her psychological state. According to the great jurist Francesco Carrara, a mother who committed an infanticide - as well as the one who had an abortion - acted "foreseeing and fearing the humiliation and the vexations which would be inflicted upon her [by the people], the coercion she would suffer from her family [...] and the threat of revenge by a betrayed husband" 27 . The fear of these "overwhelming tortures" for herself and for her illegitimate child was subjective, but it was neither unrealistic nor incomprehensible. And it had little to do with that misunderstood sense of honour that Italian laws considered a valid attenuating circumstance instead. The path opened by the theoretical elaboration of Carrara and by the Tuscan judicial experience went in a very different direction from the one that the Italian penal law pursued for almost a century and which was founded on the notion of male honor. The late deletion of the honor causa in 1981 could not be enough to make a good law. A historical reconsideration of the legal discourse, of the notions available to understand and judge infanticide - as well as maternity and sentimental relations - could in this respect contribute to precious change 28 .

Patrizia Guarnieri University of Florence

Dept of Psychology

Via di S. Salvi, 12

I-50135 Firenze

patrizia.guarnieri@unifi.it

\section{BIBLIOGRAPHY}

Ambrosetti, E. M., L'infanticidio e la legge penale, Padova, Cedam, 1992.

Arnot, M.L. and Usborne, C. (Eds.), Gender and Crime in modern Europe, London, UCL Press, 1999.

Carfora, F., Infanticidio, in Digesto Italiano, Torino, Utet, XIII, 1902-06 (dated 29 Feb. 1904), pp. 663-726.

27 Carrara (1919, p. 341).

28 I dealt with the relationship between historical analysis and an examination of the current Italian situation - where the Catholic Church considers abortion analogous to infanticide - in Guarnieri (2009). 
Carrara, F., Programma del Corso criminale. Parte speciale, I, Firenze Cammelli, 1919 ( $9^{\text {th }}$ ed., $1^{\text {st }}$. ed., 1868), pp. 321-379.

Casarini, M.P., Maternità e infanticidio a Bologna: fonti e linee di ricerca, Quaderni storici, XVII, 1982, pp. 275-285.

Ciappi, S., Gli omicidi in famiglia, in Barbagli, M., Gatti, U. (Eds.), La criminalità in Italia, Bologna, il Mulino, 2002, pp. 67-89.

Ciuffo, E., Colla, E., Mastropasqua, I., Roselletti, B. (Eds.), For a gender perspective within the Juvenile Justce System, Roma, Carocci, 2007.

Foucault, M., About the concept of «dangerous individual» in $19^{\text {th }}$ century legal psychiatry, International journal of law and psychiatry, I, 1978, pp. 1-18.

Friedman, Sh., et alii, Child murder committed by severely mentally ill mothers, Journal of forensic science, 50, 2005, pp. 1466-1471.

Guarnieri, P., Non del tutto abbandonati. Dottori, donne e neonati nel brefotrofio degli Innocenti 1850-1890, Medicina \& Storia, 4, 2002, pp. 7-51.

Guarnieri, P., Dall'accoglienza alla cura. La riforma sanitaria nel brefotrofio degl'Innocenti di Firenze, 1890-1918, in Guarnieri, P. (Ed.), Bambini e salute in Europa 1750-2000/ Children and Health in Europe 1750-2000, Firenze, Polistampa, 2004 (mon. issue of Medicina \& Storia, 7, 2004), pp. 57-100.

Guarnieri, P., Madri che uccidono. Diritto psicologia e mentalità sull'infanticidio dal $1810 \mathrm{ad}$ oggi, in Bresciani Califano, M. (ed.), Sapere e narrare. Figure della follia, Firenze, Olschki, 2005, pp. 145-174.

Guarnieri, P., Forzate analogie, Il discorso giuridico sull'infanticidio, in Guarnieri, P. (ed.), In scienza e coscienza. Maternità nascite interruzioni di gravidanza, Roma, Carocci, 2009, pp. 47-61.

Merzagora, C., Infanticidio, Digesto delle discipline penalistiche, VI, Torino, 1992, p. 395.

Passeron J.-C., Revel., J. (Eds.), Penser par cas, Paris, Éditions de l'EHESS.

Pelaja, M., Istinto di vita e amore materno: un infanticidio del 1882, Memoria, I, 1981, pp. 46-52.

Ponti, G.L., L'infanticidio e il figlicidio, in Ferracuti, F., Trattato di criminologia, medicina criminologica e psichiatria forense, Milano, Giuffrè, 1987-91, VIII, pp. 149-162.

Prosperi, A., Dare l'anima. Storia di un infanticidio, Torino, Einaudi, 2006.

Reddy, W. M., The invisible code: honor and sentiment in postrevolutionary France 18141848, Berkeley, University of California Press, 1997.

Romanelli, R., Individuo, famiglia e collettività nel codice civile della borghesia italiana, in Gherardi, R., Gozzi, G. (Eds.), Saperi della borghesia e storia dei concetti fra Otto e Novecento, «Annali dell'Istituto storico italo-germanico », 42, Bologna, Il Mulino 1995, pp. 351-399.

Rosenwein, B. H., Worrying about emotions in history, American Historical Review, CVII, 2002, pp. 821-845.

Ruggiero, K., Honor, maternity and the disciplining of women: infanticide in late nineteenthcentury Buenos Aires, Hispanic Historical Review, LXXII, 1992, pp. 353-373.

Sauer, E., Infanticide and abortion in nineteenth-century Britain, Population Studies, 32, 1978, pp. 81-93.

Selmini, R., Profili di uno studio storico sull'infanticidio, Milano, Giuffré, 1987.

Stern, D., The Motherhood Constellation: A Unified View of Parent-Infant Psychotherapy, New York, Basic Books, 1995. 
Viazzo, P.P., Bortolotto, M., Zanotto, A., Child care, infant mortality and the impact of legislation: the case of Florence's foundlings hospital, Continuity and Change, 9, 1994, pp. 243-269.

Zemon Davis, N., Fiction in the archives. Pardon tales and their tellers in the sixteenth-century France, Stanford, Stanford University Press, 1987. 